\title{
Determinants and impediments of whistle-blowing in local government councils: A case study of the South-East District Council, Botswana
}

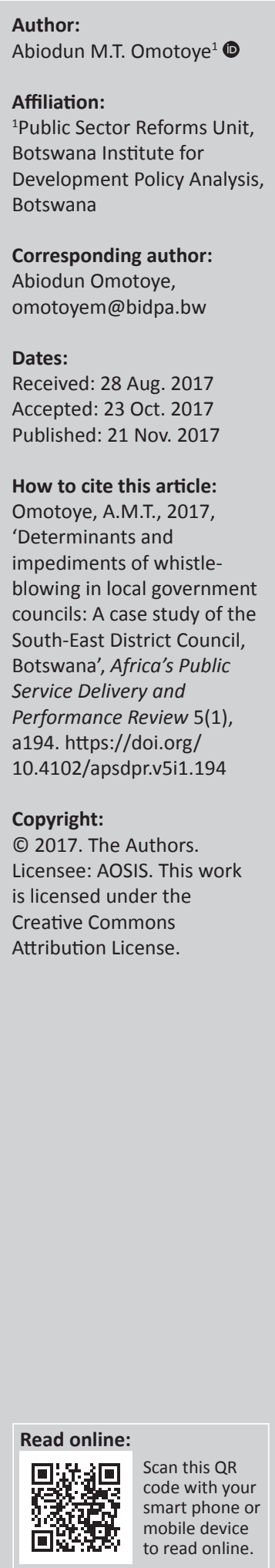

This article investigates the perceptions of public service employees regarding the role of whistle-blowing in local government. Whistle-blowing has received increased attention and support as a means of detecting and correcting wrongdoing in organisations. Yet, as this case study discusses, the absence of whistle-blower protection measures and fear of reprisal and job loss deter potential witnesses from reporting wrongdoing in the workplace. A mixed research method approach was employed to undertake the study. A self-administered questionnaire was distributed to public servants employed within the South-East District Council (SEDC) and literature related to corruption and whistle-blowing was reviewed. The findings indicate that public service employees strongly support the role whistle-blowing has to play in curbing corruption in the workplace, particularly if the corrupt activity could potentially threaten people's lives and suppress social justice. However, the absence of whistle-blower protection measures was cited as the most significant impediment to reporting wrongdoing. The article proposes the need for the SEDC to adopt effective policies and procedures that place a strong emphasis on providing protection for employees to disclose misconduct and fraudulent conduct.

\section{Introduction}

Whistle-blowing is considered to be amongst the most effective, if not the most effective, means to expose and remedy corruption, fraud and other types of wrongdoing in the public and private sectors (Wolfe et al. 2014). Globally, governments have introduced and continue to implement reforms aimed at eliminating inefficiencies, while improving the use of scarce resources. In recognising the salient need to achieve this objective, the Government of Botswana adopted a 'zero-tolerance' approach to corruption and this has been supported by the propagation of various anti-corruption measures (including the establishment of anti-corruption bodies and formulation of policies, public education and awareness campaigns, and law enforcement).

The most recent attempt to strengthen the country's national anti-corruption strategy was the enactment of the Whistle-blowing Act in 2016. Notwithstanding a relatively strong anti-corruption framework, a significant number of corruption cases have been reported in government ministries such as Transport and Communication, and Local Government and Rural Development (Directorate on Corruption and Economic Crime [DCEC] 2015). Studies (e.g. Afrobarometer 2015; Mfundisi 2008) have highlighted the perception that corruption is problematic at the national and local government level in Botswana. Perhaps, the fact that the Government of Botswana is the largest procurer of goods and services results in a significant increase in opportunities for corruption. According to the DCEC (2015), some officials have found a way of colluding with service providers to engage in corrupt practices, such as application of double standards, falsification of transactions involving public funds, payment for undelivered goods, incidences of undeclared conflicts of interest and highly inflated prices.

Corruption has an adverse impact on social and economic development because it makes the provision of goods and services an expensive undertaking. Despite the introduction of several interventions aimed at raising awareness and prevention (e.g. anti-corruption days and corruption prevention committees), these have not been effective, particularly in light of the fact that the Government of Botswana has identified combating corruption and crime as one of its key thematic areas (in addition to economic growth, diversification and investment). The underlying assumption here is that for public institutions to be considered legitimate, credible and responsive, basic tenants of transparency, accountability and incorruptibility need to be present. Secrecy (i.e. 
absence of transparency and accountability) allows corruption to thrive, results in public distrust and hinders effective public administration.

Therefore, there is a need to examine and understand the role whistle-blowing has to play as part of Botswana's overall strategy to combat corruption, as well as identify measures that can improve its effectiveness as an anti-corruption tool. Existing literature on whistle-blowing, specifically in Botswana's context, is severely limited, thus curtailing its theoretical and practical exposition as an anti-corruption tool.

\section{Objectives of the study}

The primary objective of the study was to explore the perceptions of public servants towards the role of whistleblowing in local government. Specific objectives included identifying and assessing the factors that enable and impede whistle-blowing in a local council, as well as contributing to the existing discourse on anti-corruption reforms, specifically in the context of Botswana.

\section{Local government and corruption in Botswana}

Botswana is a unitary state with a two-tier system of government - central and local government. This study focuses on the latter, specifically local councils. Other key institutions of local government in Botswana include tribal administration (supports rural development initiatives at the community level), district administration (plays a key role in rural development and the coordination, formulation, implementation and monitoring of district development plans) and land boards (statutory bodies with responsibility for allocation and control of tribal land).

Local councils in Botswana were established through the Local Government (District Councils) Act and the Townships Act in 1965. These Acts were consolidated through the Local Government Act of 2012. Elected local councils exist in 10 districts and 6 urban (city and town) councils. These are divided into administrative wings (headed by the council secretary or town clerk) and the political leadership (headed by council chairperson or mayor in the case of urban councils). Councils are accountable to the electorate and have both the authority to take decisions within their localities and discretion to allocate resources within their area of jurisdiction (CLGF 2015).

As these institutions play an important role in the planning and development process, the Ministry of Local Government and Rural Development is responsible for providing leadership and policy direction. However, the ministry notes that corruption has resulted in 'irking negative public perception over the years, which has undoubtedly impacted adversely on service delivery and establishment of partnerships with stakeholders' (MLGRD 2014). Mfundisi (2008) adds that: there are major deficits in accountability and transparency in the management of local government activities. Local communities allege corrupt practices by local government officials in the delivery of public services. (p. 62)

Furthermore, 'this situation is exacerbated by weak financial management control and inadequate capacity in most local councils in the country' (p. 62).

Councils play a critical role in all aspects of community development and more importantly poverty eradication. Councils, like other public institutions, are subject to public scrutiny and cynicism. It is therefore paramount that effective mechanisms monitoring irregularities and inefficiencies are in place to curb opportunities for corrupt and fraudulent conduct in the workplace. In the public sector, the need to identify and handle wrongdoing is of particular importance as this may harm not only organisational goals and its members but also innocent third parties who depend on welfare services from the municipality (Skivenes \& Trygstad 2016:265).

\section{Conceptual clarification}

This section discusses the concepts of whistle-blowing and public service motivation (PSM) within the context of the study.

\section{Whistle-blowing}

Practitioners and academics have defined whistle-blowing from various perspectives. For instance, Banisar (2011:2) describes it as an act of free speech, an anti-corruption tool and an internal management dispute mechanism. Early proponents, Near and Miceli (1985) define whistle-blowing as the disclosure by organisation members (former or current) of illegal, immoral or illegitimate practices under the control of their employers, to persons or organisations that may be able to effect action. The act of whistle-blowing has increasingly been recognised as an important tool in the fight against corruption as evidenced by an increase in legal protections for whistle-blowers and the prominence of anticorruption organisations. In terms of determining its effectiveness, Near and Miceli (1995:681) state that it is the extent to which the questionable or wrongful practice (or omission) is terminated at least partly because of whistleblowing. Whistle-blowing is an important organisational behaviour that can cause quantum change in modern organisations. In the public sector, whistle-blowing can also trigger fundamental reforms in the nature and role of government in society (Brewer \& Selden 1998:419).

Schultz and Harutyunyan (2015) suggest several reasons supporting the need for whistle-blowing. Firstly, some organisations may be unwilling or unable to address wrongdoing. Secondly, whistle-blowing is considered a mechanism to correct or reform organisations. Thirdly, whistle-blowing exposes bad behaviour that either the public needs to know about or which needs to be halted and corrected. Lastly, whistle-blowing may be justified as a way 
of promoting justice in that wrongdoers are held accountable for their actions. However, as the literature on whistleblowing (e.g. Banisar 2011; Fitzgerald 2013; Miceli \& Near 1984) points out, there is often reluctance by observers of organisational wrongdoing to report it, either internally or externally, because such disclosures lead to retaliation against the individual, ostracism, workplace bullying or even job loss.

Davis (1989) describes the whistle-blower as a 'tragic character'. In his view, the decision to blow the whistle should be avoided as it only brings suffering on both the individual and the organisation. Rather than being heard or praised for their courage, most whistle-blowers face indifference or mistrust and their reports are not properly investigated (Transparency International 2007:3). Given that whistle-blowing is a form of self-sacrifice and concern for the public interest, scholars (e.g. Caillier 2016; Vandenabeele 2011) argue that it is consistent with the principles of PSM.

\section{Public service motivation}

The article adopts Perry and Wise's (1990) definition of PSM, which may be understood as an individual's predisposition to respond to motives grounded primarily or uniquely in public institutions and organisations. Brewer and Selden's study (1998) found that a major obstacle to establishing a conceptual linkage between whistle-blowing and PSM is the negative stereotype some people hold about whistle-blowers. Notwithstanding, the authors conclude that whistle-blowers act in ways consistent with the theory of PSM. That is, they are motivated by concern for matters of public interest, they are high performers and they report high levels of achievement, job commitment and job satisfaction. Houston (n.d.:15) states that public employees, unlike private employees, are more likely to place a higher value on the intrinsic reward of work and less likely to place a high value on such extrinsic reward motivators (e.g. high income).

Another view is that structural arrangements such as economic incentives and protection systems have limited impact on 'traditional' whistle-blowers, that is, employees with higher levels of PSM and relatively lower levels of extrinsic motivation, as they (for moral reasons) will continue whistle-blowing regardless of the costs. In contrast individuals with lower levels of PSM, who experience some form of organisational wrongdoing, will likely be encouraged to report it if their costs by doing so are minimised or compensated (Dworkin \& Near 1997, as cited in Vandenabeele 2011).

Building on the existing literature of PSM, this study investigates the perceptions of public service employees towards the role of whistle-blowing in the public sector. It further explores organisational factors (e.g. presence of formal procedures, policies, mechanisms and leadership) that enable and impede a public service employee's decision to either report or not report a wrongdoing. The secretive nature of corruption suggests that observers of wrongdoing are best placed to influence behavioural change within the workplace by reporting illicit conduct, even when doing so may result in negative outcomes for them as individuals.

\section{Methodology}

The researcher employed a mixed method approach to undertake the study. Creswell (2013) suggests that a mixed methods design creates different, multiple perspectives, or more complete understandings, as we can confirm quantitative measures with qualitative experiences. A review of content (i.e. organisational annual reports, journal and newspaper articles, and literature on corruption and whistle-blowing) relevant to the study's objective, and the distribution of a selfadministered paper questionnaire to South-East District Council (SEDC) staff were employed to collect the data. The questionnaire was voluntary and anonymity was guaranteed to all participants, as no demographic information, such as names, gender or organisational position was required. The questionnaire was randomly distributed to 36 employees in the administrative wing of the council, with 22 questionnaires being successfully completed and returned. The researcher made several attempts (e.g. follow-ups by telephone and site visits) to retrieve the remaining questionnaires, but these were either misplaced or lost by non-respondents.

It should also be noted that corruption and whistle-blowing are sensitive subjects; hence, a reluctance to participate in studies of this nature might be a concomitant outcome. However, the intention is to provide a snapshot of the perceptions, and organisational determinants and impediments of whistleblowing in Botswana's local government. The questionnaire comprised two sections: A (employee perceptions on whistleblowing) and B (reporting of corrupt activities), which consisted of open- and closed-ended questions. A basic descriptive analysis of the collected data was processed using Excel 2016 software.

\section{Findings and discussions}

This section presents and discusses the study's key findings. Section A of the self-administered questionnaire focused on establishing employee perceptions on the role of whistleblowing in the workplace, while Section B outlined the organisational factors that either enable or impede the reporting of wrongdoing in the workplace.

\section{The role of whistle-blowing in the workplace}

The findings show that a majority of employee respondents $(82 \%)$ have a 'positive' perception towards the role whistleblowing has to play in the workplace. Respondents associate whistle-blowing with actions such as:

- reporting illicit conduct to relevant authorities (e.g. Directorate on Corruption and Economic Crime)

- informing leaders/decision-makers about any suspicious acts in the workplace

- having appropriate channels to report wrongdoing

- reporting wrongdoing without revealing identity. 
Investigating respondents' attitudes and understanding towards the role of whistle-blowing enabled the researcher to further explore the extent to which they either 'Agreed', 'Disagreed' or were 'Uncertain' on issues pertaining to whistle-blowing practices in the workplace (Table 1). Some of the major findings indicate a low level of knowledge regarding the Whistleblowing Act of 2016 and its stipulations on whistleblower protection (18\%). Awareness of internal reporting mechanisms is also low with up to $81 \%$ of the respondents either disagreeing or being uncertain of existing formal channels. However, $54 \%$ of the surveyed employees felt confident enough to report corrupt activities in the workplace.

Prior to the promulgation of the Whistleblowing Act of 2016, legal provisions for the protection of whistle-blowers or informers were stipulated in Section 45 of the Corruption and Economic Crime Act (CECA). However, the Whistleblowing Act, unlike the CECA, makes specific provisions on whistle-blower protection, as it is intended to encourage whistle-blowing and protect individuals who make disclosures to authorised persons ${ }^{1}$. As such, awareness and knowledge of the Act's stipulations (particularly on the protection of whistle-blowers) may be limited amongst most employees in the public service because of low sensitisation efforts. Protecting potential whistle-blowers or informers from reprisal or victimisation is a fundamental aspect of organisational transparency and curbing corruption in the workplace.

Eleven employee respondents indicated personally witnessing corrupt activities either within the SEDC amongst immediate colleagues or in another government department. Some of these activities included accepting bribes; stealing government funds or government property; creating waste by unnecessary or deficient goods or services; unfair selection of a contractor, consultant or a salesperson; and tolerating a situation or practice which posed a substantial and specific danger to public health or safety.

Five respondents admitted not reporting the corrupt activity, while the remaining respondents made a decision to report the activity to the following people/services: coworker, immediate supervisor, Directorate on Corruption and Economic Crime, union representative, Botswana Police Service and media. An individual's decision not to report a corrupt activity raises questions regarding their confidence in the organisation's ability to conceal their identity and protect them from possible victimisation or reprisal, particularly if the wrongdoing involved a senior member of the organisation. Similarly, it is important for the council to establish formal internal reporting channels that would focus on preventing staff from making 'unauthorised disclosures of impropriety ${ }^{2}$ to third parties (e.g. media or trade unions).

1.Institutions listed in Section 8 of the Whistleblowing Act of 2016 - Directorate on Coruption Security, Botswana Police Service, Ombudsman, Botswana Unified Revenue Service Financial Intelligence Agency, Competition Authority, Botswana Defence Force and
Botswana Prisons Service.

2.Disclosure of impropriety made to an institution not listed in Section 8 of the Whistleblowing Act of 2016.
TABLE 1: Level of awareness and attitudes towards whistle-blowing practices.

\begin{tabular}{llcc}
\hline Statement & Category & Frequency & Percentage \\
\hline I am well familiarised with the & Agree & 4 & 18.18 \\
Whistleblowing Act of 2016 and & Disagree & 11 & 50.00 \\
stipulations on the protection of & Uncertain & 7 & 31.82 \\
informers & Agree & 4 & 18.18 \\
My organisation has a formal & 10 & 45.45 \\
mechanism that encourages reporting & Disagree & 8 & 36.36 \\
of wrongdoing (e.g. whistle-blower & Uncertain & 5 & 22.73 \\
policies) & Agree & 8 & 36.36 \\
The whistle-blowing system conceals & Disagree & 9 & 40.91 \\
the identity (or identity is kept & Uncertain & 12 & 54.55 \\
anonymous) of person lodging & Agree & 6 & 27.27 \\
complaint & Disagree & 4 & 18.18 \\
I feel confident to report any corrupt & Uncertain & 0 & 0.00 \\
activity occurring in my organisation & Agree & 8 & 36.36 \\
& Disagree & 14 & 63.64 \\
$\begin{array}{l}\text { Within my organisation, there are } \\
\text { high incidences of retaliation from } \\
\text { other colleagues if someone reports }\end{array}$ & Uncertain & 4 & 18.18 \\
any corrupt activity & Agree & 13 & 59.09 \\
I would report any corrupt activity if & Disagree & 5 & 22.73 \\
there was a monetary reward or & Uncertain & 5 &
\end{tabular}

\section{Determinants of whistle-blowing}

In the context of this study, determinants refer to factors that are likely to influence or invoke action from witnesses of wrongdoing. In designing measures aimed at encouraging whistle-blowing, it is important to understand the motivational factors that influence an individual's decision to report fraud and corruption. Council employees were asked to indicate the level of importance or unimportance each of the statements provided in Table 2 would have in influencing them to report a corrupt activity in the workplace.

As Table 2 illustrates, $77 \%$ of the respondents find it very important for their identity to be kept confidential during a disclosure, as well as for them to be protected from any sort of retaliation (81\%). In addition, it is likely that a report would be made if the corrupt activity poses a threat to people's lives or suppresses social justice (72\%). Respondents were less concerned about the possibility of being positively recognised by management for reporting corruption (63\%). Council employees also felt that they would report corruption if it was considered serious in terms of cost to government. In addition, Figure 1 shows that council employees are 'very likely' to blow the whistle regardless of the individual concerned. Literature on whistle-blowing stresses that observers of wrongdoing are often unwilling to report illicit conduct when such acts are committed by higher level management or a supervisor because of the potential negative risks involved.

Nevertheless, the findings presented here are consistent with the theory of PSM. That is, surveyed council employees are motivated by a concern for the public interest and would report incidents of corruption. However, confidentiality and protection from possible retaliation are critical aspects of this process.

\section{Impediments of whistle-blowing}

Understanding the factors that impede or hinder employees from reporting wrongdoing is equally important as establishing 
TABLE 2: Factors enabling whistle-blowing

\begin{tabular}{|c|c|c|c|}
\hline Statement & Category & Frequency & Percentage \\
\hline \multirow{4}{*}{$\begin{array}{l}\text { The corrupt activity might } \\
\text { threaten people's lives and } \\
\text { suppress social justice }\end{array}$} & Very important & 16 & 72.72 \\
\hline & Somewhat important & 4 & 18.18 \\
\hline & Somewhat unimportant & 1 & 4.55 \\
\hline & Unimportant & 1 & 4.55 \\
\hline \multirow{4}{*}{$\begin{array}{l}\text { The corrupt activity was } \\
\text { something considered } \\
\text { serious in terms of costs } \\
\text { to the government }\end{array}$} & Very important & 17 & 77.27 \\
\hline & Somewhat important & 4 & 18.18 \\
\hline & Somewhat unimportant & 0 & 0.00 \\
\hline & Unimportant & 1 & 4.55 \\
\hline \multirow{4}{*}{$\begin{array}{l}\text { Some action would be } \\
\text { taken to address the } \\
\text { activity I reported }\end{array}$} & Very important & 14 & 63.63 \\
\hline & Somewhat important & 6 & 27.27 \\
\hline & Somewhat unimportant & 1 & 4.55 \\
\hline & Unimportant & 1 & 4.55 \\
\hline \multirow{4}{*}{$\begin{array}{l}\text { The wrongdoers involved } \\
\text { in the activities would be } \\
\text { rebuked }\end{array}$} & Very important & 13 & 59.09 \\
\hline & Somewhat important & 5 & 22.73 \\
\hline & Somewhat unimportant & 1 & 4.55 \\
\hline & Unimportant & 3 & 13.63 \\
\hline \multirow{4}{*}{$\begin{array}{l}\text { I would be protected from } \\
\text { any sort of retaliation }\end{array}$} & Very important & 18 & 81.81 \\
\hline & Somewhat important & 3 & 13.63 \\
\hline & Somewhat unimportant & 0 & 0.00 \\
\hline & Unimportant & 1 & 4.55 \\
\hline \multirow{4}{*}{$\begin{array}{l}\text { I would be positively } \\
\text { recognised by management } \\
\text { for reporting corruption }\end{array}$} & Very important & 62 & 27.27 \\
\hline & Somewhat important & 9 & 9.09 \\
\hline & Somewhat unimportant & 5 & 40.91 \\
\hline & Unimportant & 0 & 22.73 \\
\hline \multirow{4}{*}{$\begin{array}{l}\text { My identity would be kept } \\
\text { confidential when I } \\
\text { disclose any corruption }\end{array}$} & Very important & 17 & 77.27 \\
\hline & Somewhat important & 2 & 9.09 \\
\hline & Somewhat unimportant & 1 & 4.55 \\
\hline & Unimportant & 2 & 9.09 \\
\hline \multirow{4}{*}{$\begin{array}{l}\text { The corrupt act was } \\
\text { something you considered } \\
\text { to be a serious ethical } \\
\text { violation, although the } \\
\text { monetary costs associated } \\
\text { were small }\end{array}$} & Very important & 14 & 63.63 \\
\hline & Somewhat important & 4 & 18.18 \\
\hline & Somewhat unimportant & 2 & 9.09 \\
\hline & Unimportant & 2 & 9.09 \\
\hline
\end{tabular}

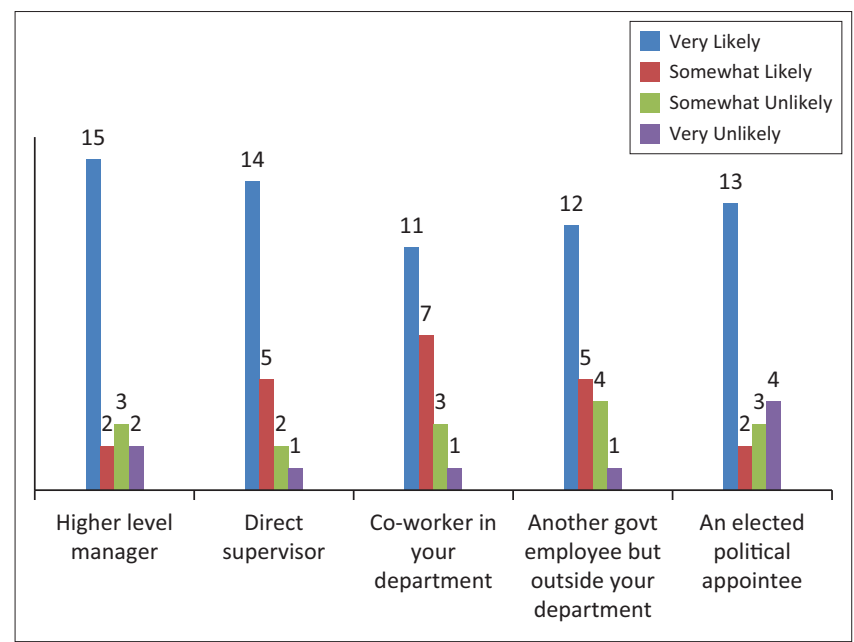

FIGURE 1: Likelihood of whistle-blowing.

the factors that motivate them to report corruption. Surveyed employees were provided with a list of factors (impediments) commonly found in whistle-blowing literature (i.e. lack of incentives, fear of punishment, fear of losing job and absence of whistle-blowing policy that protects whistle-blowers) and requested to indicate what reasons could influence an individual from not reporting corruption in the council. The results of the survey are illustrated in Figure 2. A majority $(40 \%)$ of the council employees believed that the absence of a

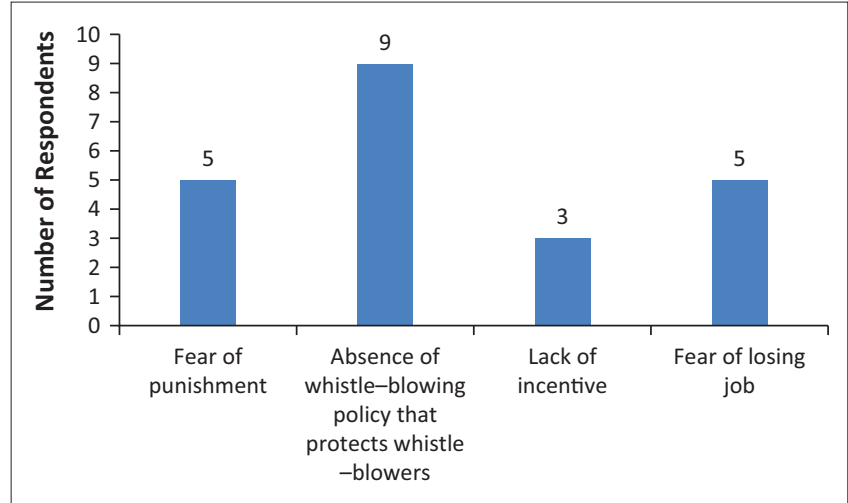

FIGURE 2: Factors impeding whistle-blowing.

whistle-blowing policy that protects whistle-blowers was a significant impediment to reporting corrupt activities in the council. Fear of losing job and fear of punishment (22\%) were the second most significant barriers to effective whistleblowing. Several respondents highlighted the underlying factors impeding effective whistle-blowing in the SEDC. One respondent (SEDC 1) stated:

Reporting corruption has not worked effectively because of the measures taken against those that report or how the cases are handled.

Another respondent (SEDC 5) was of the view that:

There is a need to define and institutionalise the reporting procedure to other corruption fighting mediums such as the media.

A third respondent (SEDC 8) emphasised that:

People fear being intimidated by those in top management. You might as well lose your job if you want to report wrongdoing.

Evidently, most council employees strongly believe that for whistle-blowing to be effective, the SEDC has to offer observers of wrongdoing the requisite protection. Protecting potential whistle-blowers from reprisal or occupational detriment is imperative to instituting a culture of transparency and accountability in the workplace. Similarly, as discussed in the previous section, council employees indicated that the most important enabler of whistle-blowing is the provision of protection measures in the workplace. Arguably, this would mitigate the closely tied concerns relating to 'fear of losing job' and 'fear of punishment'.

\section{Conclusion and recommendations Conclusion}

Whistle-blowing is not a panacea for corruption, but its intrinsic and instrumental value cannot be underestimated. Corruption not only creates distrust and a lack of confidence in public institutions, but also impacts on the efficient delivery of goods and services. It presents itself in different forms and is increasingly becoming difficult to monitor as it occurs in secret occupational spaces. This requires greater involvement of those that perceive or witness wrongdoing to speak up without fear or prejudice. 
The Whistleblowing Act of 2016 exemplifies the Government of Botswana's latest efforts to strengthen the fight against corruption. However, the study's findings reflect that while local government officials have a positive attitude towards the role whistle-blowing has to play in curbing corruption, very few respondents indicated knowing about the Act and its provisions on whistle-blower protection. This can discourage whistle-blowing. Furthermore, the absence of whistle-blower protection measures was cited as a significant barrier to reporting wrongdoing in the SEDC. The study also shows a positive link between whistle-blowing and PSM. In that, surveyed SEDC employees are concerned about the public interest, but protection from reprisal was identified as a key determinant or motivator in reporting incidents of corruption.

\section{Recommendations}

Perceptions associated with the act of whistle-blowing are polarised. The whistle-blower is identified as either a hero or a villain. Therefore, it is important for the SEDC, as well as other government entities, to embrace whistle-blowing as part of the culture of the public service, and as a tool that enhances transparency and accountability. The council's organisational policies should highlight the importance of whistle-blowing and, where possible, reward individuals that report wrongdoing.

Secondly, it is important for all council employees to be sensitised on the Whistleblowing Act. A low level of awareness amongst public servants regarding the Act's provisions on whistle-blower protection will hinder them from playing a meaningful role.

Thirdly, formal consideration should be made to enable the media and certain civil society organisations to be recognised and/or included amongst the list of institutions authorised to receive disclosures of impropriety. Despite the perceived concern that these actors might not guarantee confidentiality in withholding the identity of whistleblowers, measures (guidelines, training, etc.) should be put in place to position them to receive and handle disclosures in accordance with set standards. Individuals may find it relatively easier to approach the media or an independent non-governmental organisation such as Botswana Council of Non-Governmental Organisations compared to other institutions.

Lastly, corruption does not thrive where values of transparency and openness are present. For whistleblowing to be effective, it is vital for the political and bureaucratic leadership in councils to embrace whistleblowing as a tool that aims to curb corruption in the workplace. This echelon needs to be part of the whistleblowing protection system by ensuring that potential whistle-blowers feel confident enough to report wrongdoing without fear of victimisation.

\section{Acknowledgements}

The author is grateful to the research participants who generously shared their time to complete the questionnaires. The author also thanks Molefe Phirinyane for providing comments on an earlier version of this article.

\section{Competing interests}

The author declares that he has no financial or personal relationships which may have inappropriately influenced him in writing this article.

\section{References}

Afrobarometer, 2015, Amid perceived escalating corruption, Batswana demand officials account and declare assets, Afrobarometer Dispatch No. 19, viewed 20 February 2017, from http://afrobarometer.org/sites/default/files/publications/ February 2017, from http://afrob
Dispatch/ab_r6_dispatchno19.pdf

Banisar, D., 2011, 'Whistleblowing: International standards and developments', in I. Sandoval (ed.), Corruption and transparency: Debating the frontiers between state, market and society World Bank-Institute for social research, UNAM, Washington DC, viewed 17 January 2017, from http://papers.ssrn.com/sol3/ papers.cfm?abstract_id=1753180

Brewer, G.A. \& Selden, S.C., 1998, 'Whistle blowers in the federal civil service: New evidence of the public service ethic', Journal of Public Administration Research and Theory 8(3), 413-440. https://doi.org/10.1093/oxfordjournals.jpart.a024390

Caillier, J.G., 2016, 'Public service motivation and decisions to report wrongdoing in U.S. Federal Agencies: Is this relationship mediated by the seriousness of the wrongdoing', The American Review of Public Administration (abstract), 19 January 2016, viewed 21 May 2017, from http://journals.sagepub.com/doi/metrics/ 10.1177/0275074015626299

Commonwealth Local Government Forum, 2015, The local government system in Botswana, viewed 21 May 2017, from http://www.clgf.org.uk/botswana.

Creswell, J.W., 2013, Steps in conducting a scholarly mixed methods study, DBER Speaker Series, 48, viewed 18 October 2017, from http://digitalcommons.unl. edu/dberspeakers/48

Davis, M., 1989, 'Avoiding the tragedy of whistleblowing', Business and Professional Ethics 8(4), 3-19. https://doi.org/10.5840/bpej19898419

Directorate of Corruption and Economic Crime, 2015, 2015 Annual report, Government Printer, Gaborone.

Houston, D.J., n.d., Public service motivation: A multivariate test, viewed 17 October 2017, from https://pdfs.semanticscholar.org/577d/dd9239b677d7e6fed44a2ebf 10e5ef77ae7d.pdf

Fitzgerald, J., 2013, Whistleblowing - Systematic literature review, Aston Business School, viewed 19 January 2017, from http://www.ajustnhs.com/wp-content/ uploads/2012/05/Fitzgerald-W-B-review-2013.pdf

Mfundisi, A., 2008, 'Local governance', in Z. Maundeni (ed.), Transparency, accountability and corruption in Botswana, pp. 59-66, Made Plain Communications, Cape Town.

Miceli, M.P. \& Near, J.P., 1984, 'The relationships among beliefs, organizational position, and whistleblowing status: A discriminant analysis', Academy of Management Journal 27(4), 687-705. https://doi.org/10.2307/255873

Ministry of Local Government and Rural Development, 2014, Anti-corruption policy, Government Printer, Gaborone.

Near, J.P. \& Miceli, M.P., 1985, 'Organizational dissidence: The case of whistleblowing', Journal of Business Ethics 4(1), 1-16. https://doi.org/10.1007/BF00382668

Near, J.P. \& Miceli, M.P., 1995, 'Effective-whistle blowing', Academy of Management Review 20(3), 679-708.

Perry, J.L. \& Wise, L.R., 1990, 'The motivational bases of public service', Public Administration Review 50(3), 367-373. https://doi.org/10.2307/976618

Schultz, D. \& Harutyunyan, K., 2015, 'Combating corruption: The development of whistleblowing laws in the United States, Europe, and Armenia', International Comparative Jurisprudence 1(2), 87-97. https://doi.org/10.1016/j.icj.2015.12.005

Skivenes, M. \& Trygstad, S.C., 2016, 'Whistleblowing in local government: An empirical study of contact patterns and whistleblowing in 20 Norwegian municipalities' Scandinavian Political Studies 39(3), 264-289. https://doi.org/10.1111/14679477.12066

Transparency International, 2007, Alternative to silence: Whistleblower protection in 10 European countries, Transparency International, Berlin.

Vandenabeele, W., 2011, 'The relationship between public service motivation and whistle-blowing intention: Interplay of individual and structural elements', paper presented at the Annual EGPA Conference, SGIII, Bucharest, Romania, 07-11 September.

Wolfe, S., Worth, M., Dreyfus, S. \& Brown, A.J., 2014, Whistleblower protection laws in G20 countries, Transparency International Australia, viewed 20 March 2017, from https://www.transparency.de/fileadmin/pdfs/Themen/Hinweisgebersysteme/ Whistleblower-Protection-Laws-in-G20-Countries-Priorities-for-Action.pdf 